\title{
Evaluasi Kualitatif Antibiotik Metode Gyssens dengan Konsep Regulasi Antimikroba Sistem Prospektif RASPRO pada Pneumonia di Ruang Rawat Intensif Anak
}

Rinna W. Sundariningrum, ${ }^{1}$ Darmawan Budi Setyanto, ${ }^{2}$ Ronald Irwanto Natadidjaja ${ }^{3}$

${ }^{1}$ Bagian Ilmu Kesehatan Anak Rumah Sakit Hermina Bekasi, ${ }^{2}$ Departemen Ilmu Kesehatan Anak Fakultas Kedokteran Universitas Indonesia/RSUPN Dr. Cipto Mangunkusumo, ${ }^{3}$ Departemen Ilmu Penyakit Dalam Fakultas Kedokteran Trisakti dan Yayasan Pelita RASPRO Indonesia

Latar belakang. Pneumonia masih paling sering sebagai infeksi primer maupun infeksi sekunder dalam perawatan anak di ruang rawat intensif. Penggunaan antibiotik yang tidak tepat dapat meningkatkan morbiditas, mortalitas, pengobatan lebih mahal, dan resistensi antibiotik.

Tujuan. Mengevaluasi penggunaan antibiotik secara kualitatif pada pasien pneumonia menggunakan metode Gyssens dengan konsep RASPRO.

Metode. Penelitian deskriprif retrospektif berdasarkan data rekam medis pasien pneumonia di ruang intensif anak RS Hermina Bekasi, periode bulan Mei sampai Oktober 2019. Antibiotik dievaluasi secara kualitatif menggunakan metode Gyssens dengan konsep RASPRO. Hasil. Didapatkan $51(14,46 \%)$ pasien dengan pneumonia berat. Digunakan 119 antibiotik; terdiri dari 90 (75,63\%) empiris dan 29 (24,37\%) definitif. Ampisilin sulbaktam merupakan antibiotik paling banyak digunakan (15,98\%), diikuti sefotaksim (15,12\%), meropenem (13,44\%), azithromisin (11,78\%), dan seftriakson (10,92\%). Berdasarkan metode Gyssens dengan konsep RASPRO, penggunaan antibiotik tepat (kategori 0) sebanyak 63,02\%, sedangkan tidak tepat, yaitu 1,68\% kategori IVa (alternatif lebih efektif), 22,69\% kategori IIIa (durasi terlalu panjang) 9,24\% kategori IIIb (durasi terlalu singkat), dan 3,36\% kategori IIa (tidak tepat dosis).

Kesimpulan. Pemakaian antibiotik tepat didapatkan hasil cukup baik, yaitu 63,03\%. Konsep RASPRO dapat digunakan untuk mengurangi bias subyektifitas dalam penilaian antibiotik secara kualitatif dengan metode Gyssens pada pneumonia di ruang intensif anak. Sari Pediatri 2020;22(2):109-14

Kata kunci: evaluasi kualitatif, antibiotik, metode Gyssens, pneumonia anak

\section{Qualitative Evaluation of Antibiotic with Gyssens Method by RASPRO Concept for Pneumonia at Pediatric Intensive Care Unit}

Rinna W. Sundariningrum, ${ }^{1}$ Darmawan Budi Setyanto, ${ }^{2}$ Ronald Irwanto Natadidjaja ${ }^{3}$

Background. Pneumonia remains the commonest infective reason for admission to intensive care as well as being the most common secondary infection acquired whilst in the pediatric intensive care unit. Inappropriate use of antibiotics can increase morbidity, mortality, patient cost, and antibiotic resistance.

Objective. To qualitatively evaluate antibiotic use in pneumonia with The Gyssens method by RASPRO concept.

Methods. We performed a descriptive, retrospective study data based on medical records of patients with pneumonia who admitted to the pediatric intensive care unit in Hermina Bekasi Hospital from May to October 2019. Records were evaluation its qualitative antibiotic using the Gyssens method by RASPRO concept.

Result. This study discovered 51 cases (14,46\%) of severe pneumonia. We found 119 antibiotics uses including 90 (75,63\%) empirical therapies and 29 (24,37\%) devinitive therapies. Ampicilin sulbactam was the most common antibiotic used (15,98\%), followed by cefotaxime $(15,12 \%)$, meropenem $(13,44 \%)$, azithromycin $(11,78 \%)$ and ceftriaxone $(10,92 \%)$. Based on Gyssens method by RASPRO concept, appropriate antibiotic use (category 0) accounted for 63,02\%, while inappropriated use accounted for $1,68 \%$ category IVa (improper; other antibiotics were more effective), 22,69\% category IIIa (improper; duration too long), 9,24\% category IIIb (improper; duration too short) and 3,36\% category IIa (improper; incorrect dose).

Conclusion. Appropriate use of antibiotics showed quite good results, namely 63,03\%. The RASPRO concept can be used to reduce subjectivity bias in qualitative antibiotic assessments by the Gyssens method for pneumonia treated in the pediatric intensive care unit. Sari Pediatri 2020;22(2):109-14

Keywords: qualitative evaluation, antibiotic, Gyssens method, children pneumonia

Alamat korespondensi: Rinna W. Sundariningrum, Rumah Sakit Hermina Bekasi. Jl. Kemakmuran No. 39 Bekasi. Email: wamiladr@gmail.com 
Rinna W. Sundariningrum dkk.: Evaluasi kualitatif antibiotik metode Gyssens dengan konsep RASPRO pada pneumonia

$\mathrm{P}$ neumonia masih merupakan penyakit dengan angka kesakitan dan kematian tinggi pada anak di bawah usia 5 tahun. Sebagian besar disebabkan oleh infeksi bakteri atau virus, dan sebagian kecil disebabkan oleh faktor non infeksi seperti aspirasi. ${ }^{1-4}$

Berdasarkan Peraturan Menteri Kesehatan Republik Indonesia (PERMENKES) no. 8 tahun 2015 setiap rumah sakit diwajibkan mempunyai Program Pengendalian Resistensi Antimikroba (PPRA), yaitu upaya yang ditujukan untuk mencegah dan/atau menurunkan adanya kejadian mikroba resisten. Dalam PERMENKES no. 8 tahun 2015 digunakan alur penilaian menurut tabel Gyssens untuk menentukan kategori kualitas penggunaan setiap antibiotik yang digunakan..$^{5}$ Pada tahun 1992, Gyssens $\mathrm{dkk}^{6}$ pertama kali mengembangkan diagram alur untuk mengevaluasi berbagai hal yang berkaitan dengan pemberian antibiotik.

Konsep Regulasi Antimikroba Sistem Prospektif (RASPRO) merupakan sebuah konsep penatalayanan antimikroba yang digagas oleh dr. Ronald Irwanto Natadidjadja, SpPD-KPTI, FINASIM, dan mendapatkan sertifikat hak cipta dari Kementerian Hukum dan HAM Republik Indonesia pada tahun 2018 dengan nomor 000121541. Melalui Perhimpunan Pengendalian Infeksi Indonesia (PERDALIN), dibuatkan sistem RASPRO yang terkonsep, serta diadakan pula pelatihan berkala, yang bertujuan memudahkan penerapan program yang dicanangkan dalam PERMENKES no. 8 tahun 2015 tersebut di rumah sakit agar berlangsung secara baku, terpadu, berkesinambungan, terukur, dan dapat dievaluasi. ${ }^{7}$ Sampai dengan saat ini, evaluasi antibiotik pada pasien pneumonia di ruang rawat intensif anak belum pernah dilaporkan. Tujuan penelitian ini adalah untuk melakukan evaluasi penggunaan antibiotik pada pasien pneumonia yang dirawat di ruang intensif anak RS Hermina Bekasi secara kualitatif dengan menggunakan tabel Gyssens dengan konsep RASPRO.

\section{Metode}

Penelitian ini merupakan penelitian deskriptif dilakukan dengan pengambilan data retrospektif berdasarkan rekam medis pasien yang dirawat di ruang intensif anak RS Hermina Bekasi selama periode bulan Mei sampai dengan Oktober 2019. Subjek penelitian yang menjadi kriteria inklusi adalah semua pasien yang didiagnosis pneumonia dan dirawat di ruang rawat intensif anak dalam kurun waktu penelitian, dengan usia 1 bulan sampai 18 tahun yang mendapat terapi antibiotik.

Dilakukan pencatatan data demografi pasien (usia, jenis kelamin, tanggal masuk dan keluar rumah sakit, asal rujukan, berat badan), hasil biakan dan uji sensitivitas, jenis antibiotik yang diberikan serta kondisi pasien saat keluar dari ruang perawatan intensif anak (sembuh atau meninggal). Pasien dinyatakan sembuh bila keluar dari perawatan intensif anak dalam keadaan stabil dan menjalani perawatan di ruang rawat biasa. Dosis antibiotik yang digunakan adalah berdasarkan buku dosis obat yang ditulis oleh Frank Shann.

Evaluasi menggunakan tabel Gyssens dilakukan dengan cara menggolongkan setiap pemberian antibiotik menjadi 6 kategori, yaitu kategori VI (penggunaan tidak tepat karena catatan rekam medis tidak lengkap untuk dievaluasi), kategori $\mathrm{V}$ (penggunaan tidak tepat karena tidak sesuai indikasi), kategori IVa (penggunaan tidak tepat karena ada antibiotik lain yang lebih efektif), kategori IVb (penggunaan tidak tepat karena ada antibiotik lain yang lebih aman), kategori IVc (penggunaan tidak tepat karena ada antibiotik lain yang lebih murah), kategori IVd (penggunaan tidak tepat karena ada antibiotik lain yang spektrumnya lebih sempit atau spesifik), kategori IIIa (penggunaan tidak tepat karena terlalu panjang pemberiannya), kategori IIIb (penggunaan tidak tepat karena terlalu singkat pemberiannya), kategori IIa (penggunaan tidak tepat dosis pemberian), kategori IIb (penggunaan tidak tepat interval pemberian), kategori IIc (penggunaan tidak tepat cara pemberian), serta kategori I (waktu pemberian tidak tepat) dan 0 dinyatakan penggunaan antibiotik tepat dan rasional (tidak termasuk kategori I sampai VI).

Pengisian tabel Gyssens menggunakan konsep RASPRO bertujuan untuk meminimalkan subjektifitas dan menyeragamkan pelaporan. Pada konsep RASPRO dibuat kesepakatan kepatuhan penggunaan antibiotik oleh Dokter Penanggung Jawab Pasien (DPJP) pada Panduan Penggunaan Antibiotik (PPAB) rumah sakit. Setiap tabel Gyssens digunakan untuk evaluasi setiap antibiotik. Penggunaan antibiotik dikatakan terlalu singkat bila digunakan kurang dari 3 hari, dan terlalu panjang apabila digunakan lebih dari 7 hari. Pengisian tabel Gyssens kategori IVa, IVb, IVc, dan IVd akan teredukasi bila antibiotik yang diberikan sesuai dengan pilihan stratifikasi lini antibiotik untuk pneumonia, yang tercantum dalam PPAB. Untuk kategori V disepakati setiap DPJP harus mengisi fokus infeksi, dalam penelitian ini fokus infeksi adalah pada jaringan paru. 


\section{Hasil}

Selama periode penelitian, jumlah pasien di ruang intensif anak 123 pasien, tetapi yang memenuhi kriteria inklusi 51 pasien. Karakteristik subjek penelitian tertera pada Tabel 1.

Seluruh pasien mendapat terapi antibiotik. Penggunaan antibiotik didapatkan 119 antibiotik; 14 pasien mendapatkan kombinasi dua antibiotik secara bersamaan dan juga 14 pasien mendapatkan kombinasi tiga antibiotik pada saat bersamaan. Penggunaan antibiotik empiris 90 antibiotik, sedangkan antibiotik definitif sesuai dengan hasil kultur 29 antibiotik. Antibiotik yang paling banyak diberikan adalah ampisilin sulbaktam $(15,98 \%)$, sefotaksim $(15,12 \%)$, meropenem $(13,44 \%)$, azithromisin $(11,78 \%)$, dan seftriakson (10,92\%). Antibiotik yang digunakan tertera pada Tabel 2.

Penilaian kualitatif antibiotik metode Gyssens dengan konsep RASPRO dilakukan pada semua antibiotik sesuai dengan indikasi. Di antara 119 antibiotik yang digunakan, 63,03\%

Tabel 1. Karakteristik subjek penelitian

\begin{tabular}{lc}
\hline Karakteristik & $\mathrm{n}=51$ \\
\hline Jenis kelamin & $30(30 / 51)$ \\
$\quad$ Lelaki & $21(21 / 51)$ \\
$\quad$ Perempuan & \\
Usia & $17(17 / 51)$ \\
$0-<6$ bulan & $34(34 / 51)$ \\
$\geq 6$ bulan -9 tahun & \\
Rujukan & $39(39 / 51)$ \\
Datang sendiri & $12(12 / 51)$ \\
Rumah sakit lain & \\
Status gizi & $2(2 / 51)$ \\
$\quad$ Gizi lebih & $30(30 / 51)$ \\
Baik & $9(9 / 51)$ \\
Kurang & $10(10 / 51)$ \\
Buruk & \\
Penggunaan ventilator & $30(30 / 51)$ \\
$\quad$ Ya & $21(21 / 51)$ \\
Tidak & \\
Lama rawat ruang ERIA & $22(22 / 51)$ \\
$\leq 4$ hari & $29(29 / 51)$ \\
$>4$ hari & $24(24 / 51)$ \\
Lama rawat inap RS 7 hari & $27(27 / 51)$ \\
$\quad 7$ hari & \\
Huaran & \\
$\quad$ Meninggal & \\
\hline
\end{tabular}

adalah pemakaian antibiotik tepat dan rasional (kriteria 0 ), sedangkan penggunaan antibiotik tidak tepat 36,98\% (kriteria IVa 1,68\%, IIIa 22,69\%, IIIb 9,24\% dan IIa 3,36\%). Tabel 3 menampilkan evaluasi antibiotik berdasarkan tabel Gyssens.

Tidak semua pasien yang dirawat dilakukan pemeriksaan kultur. Tabel 4 memperlihatkan hasil biakan tidak tumbuh dan yang tumbuh pada kultur darah ataupun kultur sputum. Bakteri yang tumbuh berturut-turut mulai dari yang terbanyak adalah

Tabel 2. Jumlah penggunaan antibiotik

\begin{tabular}{lcc}
\hline Jenis antibiotik & Jumlah & $\%$ \\
\hline Ampisillin sulbaktam & 19 & 15,98 \\
Sefotaksim & 18 & 15,12 \\
Meropenem & 16 & 13,44 \\
Azithromisin & 14 & 11,78 \\
Seftriakson & 13 & 10,92 \\
Gentamisin & 12 & 10,08 \\
Amikasin & 4 & 3,36 \\
Levofloksasin & 4 & 3,36 \\
Piperasilin tazobaktam & 4 & 3,36 \\
Doripenem & 3 & 2,52 \\
Ampisilin & 2 & 1,68 \\
Kloramfenikol & 2 & 1,68 \\
Linezolid & 2 & 1,68 \\
Metronidazol & 2 & 1,68 \\
Ciprofloksasin & 1 & 0,84 \\
Sefepim & 1 & 0,84 \\
Seftazidim & 1 & 0,84 \\
Tigesiklin & 1 & 0,84 \\
\hline Jumlah & 119 & 100 \\
\hline
\end{tabular}

Tabel 3. Evaluasi antibiotik berdasarkan tabel Gyssens

\begin{tabular}{|c|c|c|c|}
\hline & Kategori Gyssens & $\begin{array}{c}\text { Jumlah } \\
\text { antibiotik }\end{array}$ & $\%$ \\
\hline VI. & Data tidak lengkap & 0 & 0 \\
\hline V. & Indikasi antibiotik tidak sesuai & 0 & 0 \\
\hline IVa. & Alternatif lain lebih efektif & 2 & 1,68 \\
\hline IVb. & Alternatif lain kurang toksik & 0 & 0 \\
\hline IVc. & Alternatif lain lebih murah & 0 & 0 \\
\hline $\begin{array}{l}\text { IVd. } \\
\text { IIIa. }\end{array}$ & $\begin{array}{l}\text { Alternatif lain spektrum lebih } \\
\text { sempit }\end{array}$ & 0 & 0 \\
\hline IIIb. & Durasi terlalu panjang & 27 & 2,69 \\
\hline IIa. & Durasi terlalu singkat & 11 & 9,24 \\
\hline IIb. & Dosis tidak tepat & 4 & 3,36 \\
\hline IIc. & Interval tidak tepat & 0 & 0 \\
\hline I. & Rute tidak tepat & 0 & 0 \\
\hline \multirow[t]{2}{*}{0.} & Waktu pemberian tidak tepat & 0 & 0 \\
\hline & Pemakaian antibiotik tepat & 75 & 3,03 \\
\hline
\end{tabular}


Rinna W. Sundariningrum dkk.: Evaluasi kualitatif antibiotik metode Gyssens dengan konsep RASPRO pada pneumonia

bakteri Acinetobacter baumanii, Pseudomonas aeruginosa, Klebsiella pneumonia, Serratia marcescens, Acinobacter xylosidans dan Staphylococcus hominis.

Tabel 4. Hasil biakan yang tumbuh

\begin{tabular}{lc}
\hline Hasil biakan & Jumlah \\
\hline Darah & 9 \\
Steril & 3 \\
Acinetobacter baumanii & 2 \\
Klebsiella pneumonia & 1 \\
Pseudomonas aeruginosa & 1 \\
$\quad$ Staphylococcus hominis & \\
Sputum & 5 \\
Acinetobacter baumanii & 3 \\
Pseudomonas aeruginosa & 2 \\
Klebsiella pneumonia & 1 \\
Acinetobacter xylosidans & 1 \\
Serratia marcescens &
\end{tabular}

\section{Pembahasan}

Pneumonia yang dirawat di ruang intensif anak adalah 14,46\%. Angka kejadian tersebut tidak berbeda jauh dari yang dilaporkan oleh Benet dan kawan-kawan tahun 2017. 3 Penelitian Benet merupakan penelitian observasional bersifat prospektif, multisenter dari beberapa tempat, yaitu India, Madagaskar, Mali, dan Paraguay. Pada penelitian multisenter tersebut didapatkan 405 pasien pneumonia, dan 17,3\% mengalami hipoksemia dengan saturasi oksigen $<90 \%$. Jumlah kasus yang meninggal pada penelitian Benet dilaporkan 3,5\%, sedangkan pada penelitian ini 5,69\% dari total pasien perawatan intensif anak. Beberapa penelitian lain di India pada anak usia 1-59 bulan dengan pneumonia melaporkan angka kematian berkisar $8,2 \%$ sampai $47 \% .^{8-10}$ Sementara penelitian di Lombok, pada pasien pneumonia berat yang dirawat di ruang intensif dilaporkan angka kematian antara 3,4\% sampai $12 \% .{ }^{11}$

Dari 119 antibiotik, digunakan 90 (75,63\%) antibiotik empiris, sedangkan yang sesuai kultur 29 $(24,37 \%)$ antibiotik. Idealnya, tatalaksana pneumonia sesuai dengan kuman penyebabnya dan diberikan antibiotik yang sensitif terhadap kuman tersebut, tetapi karena berbagai kendala diagnostik etiologi, untuk semua pasien pneumonia diberikan antibiotik secara empiris. Pneumonia viral seharusnya tidak diberikan antibiotik, tetapi pasien dapat diberi antibiotik apabila terdapat kesulitan membedakan infeksi virus dengan bakteri, disamping kemungkinan infeksi bakteri sekunder yang tidak dapat disingkirkan. ${ }^{4}$ Pemberian antibiotik definitif pada penelitian ini rendah, disebabkan tidak semua pasien dilakukan pengambilan biakan spesimen sebelum pemberian antibiotik. Sebaiknya, semua pasien dilakukan biakan spesimen sebelum menggunakan antibiotik untuk mengidentifikasi bakteri penyebab infeksi karena setiap bakteri mempunyai sifat masingmasing dalam menimbulkan penyakit. ${ }^{12}$ Penyebab lain pertumbuhan biakan yang rendah adalah waktu kurang tepat saat pengambilan spesimen dan volume spesimen yang dibutuhkan untuk pertumbuhan biakan seringkali kurang. Volume spesimen darah untuk pemeriksaan biakan memerlukan jumlah relatif cukup banyak karena diperlukan dua spesimen darah dari dua tempat yang berbeda pada waktu yang bersamaan untuk menghindari kemungkinan hasil biakan terkontaminasi. ${ }^{13}$

Jenis antibiotik yang digunakan terbanyak berturutturut adalah ampisilin sulbaktam 15,98\%, sefotaksim $15,12 \%$, meropenem $13,44 \%$, azithromisin $11,78 \%$, dan seftriakson 10,92 .

Penggunaan antibiotik golongan penisillin dan sefalosporin pada penelitian ini tampak masih lebih banyak dibandingkan golongan karbapenem, quinolone, ataupun oxazolindinone dan glikopeptida. Padahal, penggunaan antibiotik golongan glikopeptida, seperti vankomisin tidak digunakan. Hal ini karena pada Panduan Penggunaan Antibiotik (PPAB) rumah sakit, seluruh antibiotik digolongkan menjadi lini I, lini II, dan lini III. Antibiotik golongan karbapenem, sefalosporin generasi IV, oxazolindinone dan glikopeptida digolongkan dalam antibiotik lini III, sangat dibatasi penggunaannya dan harus melalui persetujuan tim PPRA. Pada penelitian ini, untuk kasus pneumonia berat agaknya masih dimungkinkan untuk pemberian tatalaksana antibiotik golongan penisillin dan sefalosporin.

Dengan metode RASPRO, PPAB disusun berdasarkan stratifikasi risiko pasien yang terinfeksi bakteri multisensitif dan multiresisten, sebelum akhirnya antibiotik definitif diberikan berdasarkan hasil kultur resistensi. Pembagian stratifikasi risiko pasien bertujuan sebagai acuan pemberian antibiotik empiris dan acuan restriksi antibiotik berdasarkan kesepakatan yang berlaku, serta sebagai evaluasi antibiotik dalam kesesuaian indikasinya. ${ }^{7}$

Risiko pasien dibagi menjadi tiga stratifikasi. Stratifikasi risiko pasien tipe I, pasien berisiko terinfeksi kuman multisensitif, yaitu pada pasien tanpa kormobid dan tidak ada riwayat perawatan atau penggunaan antibiotik lebih dari 90 hari. Pasien tipe ini diberikan 
antibiotik lini I. Stratifikasi risiko pasien tipe II, pasien berisiko terinfeksi bakteri Extended Spectrum Beta-Lactamase (ESBL), pasien mempunyai komorbid dengan riwayat perawatan rumah sakit atau penggunaan antibiotik kurang dari 90 hari. Pasien tipe ini diberikan antibiotik lini II. Sementara stratifikasi risiko pasien tipe III, pasien berisiko terinfeksi bakteri Multidrugresistant (MDR), Pseudomonas sp, Acinetobacter sp, Methicillin Resistant Staphylococcus aureus (MRSA) atau Methicillin Resistant Staphylococcus epidermis (MRSE), pasien mempunyai komorbid, riwayat tindakan invasif dan penggunaan antibiotik kurang dari 90 hari. Pasien tipe ini diberikan antibiotik lini III. ${ }^{7,14}$

Evaluasi penggunaan antibiotik empiris secara berkala diperlukan dan disesuaikan dengan pola pertumbuhan bakteri. Setelah hasil biakan dan uji sensitivitas ada, harus diupayakan mempersempit spektrum antibiotik yang diberikan sesuai dengan hasil uji sensitivitas tersebut, karena upaya ini dapat mengurangi toksisitas, mencegah resistensi antibiotik dan biaya pengobatan. Evaluasi penggunaan antibiotik dilakukan dengan metode audit kuantitas dan audit kualitas. ${ }^{6}$

Pada penelitian ini evaluasi kualitatif antibiotik metode Gyssens dengan konsep RASPRO didapatkan antibiotik tepat dan rasional (kategori 0) adalah $63,03 \%$, lebih tinggi dibandingkan penelitian di ruang intensif anak RSCM tahun 2012 oleh Yuniar $\mathrm{dkk},{ }^{15}$ yang mendapatkan hasil $53 \%$, juga lebih tinggi dari penelitian di ruang rawat bangsal anak RSCM tahun 2011 (39,6\%), ${ }^{16}$ maupun dibandingkan dengan penelitian di Rembang, Jawa Tengah, tahun 2014 pada pasien pneumonia di bangsal perawatan anak $(49,7 \%) .{ }^{17}$ Penelitian terbaru tahun 2019, di Yogyakarta oleh Faizin d $\mathrm{kk}$ melaporkan hasil 40,7\% penggunaan antibiotik tepat pada seluruh pasien anak yang dirawat. ${ }^{18}$ Penelitian di luar negeri oleh Cusini d kk di Switzerland, ${ }^{19}$ didapatkan data pada pasien dewasa 46,4\%, sedangkan penelitian metode Gyssens di luar negeri pada pasien anak hingga saat ini belum didapatkan data.

Dengan menggunakan konsep RASPRO, maka bias subjektifitas dalam pengisian tabel Gyssens bias dikurangi. Dalam konsep RASPRO, setiap pemberian antibiotik awal harus mengisi tabel RASAL (RASPRO alur antibiotik awal) sehingga dalam pengisiannya akan didapatkan anjuran pemakaian antibiotik dengan lini yang sesuai dengan stratifikasi pasien saat awal masuk. Bila selama perawatan dilakukan penggantian antibiotik, maka harus mengisi tabel RASLAN (RASPRO alur antibiotik lanjutan) yang akan memberikan panduan penggantian antibiotik sesuai lini berdasarkan kondisi pasien.?

Penggunaan dosis kurang tepat (kategori IIa) terjadi 3,36\%. Penggunaan dosis yang kurang tepat ini menyebabkan proses penyembuhan lama sehingga lama rawat di ruang intensif anak akan bertambah, disamping juga menyebabkan terjadinya resisten antibiotik. ${ }^{20,21}$ Pada 22,69\% pemakaian antibiotik tidak tepat disebabkan durasi terlalu panjang (kategori IIIa). Durasi terapi antibiotik lebih lama diperlukan pada kasus pneumonia berat yang disertai gagal nafas sehingga diperlukan ventilator. Pada penelitian ini jumlah pasien pneumonia berat yang menggunakan ventilator 30 (30/51) pasien. Respon terhadap pemberian antibiotik sebaiknya dievaluasi setelah tiga hari. Bila antibiotik yang diberikan tidak memberikan respon, maka harus dievaluasi mengenai kemungkinan adanya komplikasi, sumber infeksi lain atau resisten antibiotik. ${ }^{20,21}$

Penyebab lain penggunaan antibiotik tidak tepat adalah durasi terlalu singkat (kategori IIIb), pada 9,24\%, semuanya diakibatkan pasien meninggal sebelum perawatan tiga hari di ruang intensif anak. Pemakaian antibiotik tidak tepat karena ada alternatif lebih efektif (kategori IVa) terdapat pada pemakaian dua antibiotik (1,68\%). Keadaan ini disebabkan antibiotik yang digunakan tidak sesuai dengan hasil kultur sensitifitas pasien.

Secara umum, bakteri yang paling berperan penting dalam pneumonia adalah Streptococcus pneumoniae, Haemophilus influenzae, Staphylococcus aureus, Streptokokus grup B, serta kuman atipik klamidia dan mikoplasma. ${ }^{1,4,8}$ Pada penelitian ini bakteri yang berhasil diidentifikasi adalah Acinetobacter baumanii, Pseudomonas aeruginosa, Klebsiella pneumonia, Serratia marcescens, Acinobacter xylosidans dan Staphylococcus hominis. Bakteri yang ditemukan tersebut sebagian besar adalah bakteri Gram negatif, kecuali Staphylococcus hominis merupakan bakteri Gram positif. Bakteri ini merupakan penyebab tersering infeksi nasokomial yang sangat berpotensi menimbulkan resisten terhadap sebagian besar antibiotik. Keadaan ini tidak jauh berbeda dengan penelitian Putra dkk ${ }^{22}$ di Surabaya tahun 2019, pada hasil biakan darah dan sputum paling banyak jenis bakteri Gram negatif yang ditemukan.

Keterbatasan penelitian ini dilakukan secara retrospektif dengan menggunakan data rekam medis dan pemeriksaan biakan tidak dilakukan pada semua pasien. Dibutuhkan penelitian lebih lanjut secara prospektif dengan jumlah sampel lebih banyak dan pemeriksaan biakan dikerjakan pada semua sampel agar didapatkan hasil lebih akurat dalam penilaian antibiotik secara kualitatif. 
Rinna W. Sundariningrum dkk.: Evaluasi kualitatif antibiotik metode Gyssens dengan konsep RASPRO pada pneumonia

\section{Kesimpulan}

Pemakaian antibiotik tepat dan rasional pada penelitian ini didapatkan hasil cukup baik yaitu 63,03\%. Konsep RASPRO dapat digunakan untuk mengurangi bias subjektifitas dalam penilaian antibiotik secara kualitatif dengan metode Gyssens pada pneumonia yang dirawat di ruang intensif anak.

\section{Daftar pustaka}

1. Said M. Pneumonia. Dalam: Rahajoe NN, Supriyatno B, Setyanto DB, penyunting. Buku Ajar Respirologi Anak. Edisi pertama. Jakarta: Badan Penerbit Ikatan Dokter Anak Indonesia; 2010.h.325-39.

2. Messinger AI, Kupfer O, Hurst A, Parker S. Management of pediatric community-acquired bacterial pneumonia. Pediatr Rev 2017;38:394-409.

3. Benet T, Picot VS, Awasthi S, Pandey N, Bavdekar A, Kawade A, dkk. Severity of pneumonia in under 5-year-old children from developing countries: a multicenter, prospective, observational study. Am J Trop Med Hyg 2017;97:68-76.

4. Supriyatno B. Infeksi respiratorik bawah akut pada anak. Sari Pediatri 2006;2:100-6.

5. Kemkes RI. Peraturan Menteri Kesehatan Republik Indonesia No.8 Tahun 2015 tentang Program Pengendalian Resistensi Antimikroba di rumah sakit. Diakses pada 2 Agustus 2020. Didapat dari: http://ditjenpp.kemenkumham.go.id/arsip/ bn/2015/bn334-2015.pdf.

6. Gyssens IC, Van den Broek PJ, Kullberg BJ, Hekster YA, Van den Meer JWM. Optimizing antimicrobial theraphy. A method for antimicrobial drug use evaluation. J Antimicrob Chemother 1992;30:742-7.

7. Irwanto R. Konsep RASPRO. Metode tataguna antibiotik bijak dalam rangka menjalankan fungsi PPRA di rumah sakit, 2018. (Tidak dipublikasi).

8. Goodman D. Crocker ME, Pervaiz F, McCollum ED, Steenland K, Simkovich SM, dkk. Challenges in the diagnosis of paediatric pneumonia in intervention field trials: recommendations from a pneumonia field trial working group. Lancet Respir Med 2019;7:1068-83.

9. Ramachandran P, Nedunchelian K, Vengatesan A, Suresh S. Risk factors for mortality in community aquired pneumonia among children aged 1-59 months admitted in a referral hospital. Indian Pediatr 2012;49:889-95.

10. Tiewsoh K, Lodha R, Pandey RM, Broor S, Kalaivani M, Kabra SK. Factors determining the outcome of children hospitalized with severe pneumonia. BMC Pediatrics 2009;9:15. Diakses pada 24 Juli 2020. Didapat dari: https://www.biomedcentral. com/1471-2431/9/15.

11. Djelantik IGG, Gessner BD, Sutanto A, Steinhoff M, Linehan $\mathrm{M}$, Moulton LH, dkk. Case fatality proportions and predictive factors for mortality among children hospitalized with severe pneumonia in a rural developing country setting. J Trop Peadiatr 2003;49:327-32.

12. Stuckey-Schrock K, Hayes B, George CM. Communityacquired pneumonia in children. Am Fam Physician 2012;86:661-7.

13. Murthy R. Implementation of strategies to control antimicrobial resistance. Chest 2001;119:405s-11s.

14. Slavcovici A, Streinu-Cercel A, Tatulescu D, Radulescu A, Mera S, Marcu C, dkk. The role of risk factors ("carmeli score") and infective andocarditis classification in the assessment of appropriate empirical therapy. Therapeutics Pharmacol Clin Toxicol 2009;13:52-16.

15. Yuniar I, Karyanti MR, Tambunan T, Rizkyani NA. Evaluasi penggunaan antibiotik dengan kartu monitoring antibiotik gyssens. Sari Pediatri 2013;14:384-90.

16. Satari HI, Firmansyah A, Theresia. Qualitative evaluation of antibiotic usage in pediatric patients. Pediatr Indones 2011;51:303-9.

17. Rahayu YD, Wahyono D, Mustofa. Evaluasi rasionalitas penggunaan antibiotic terhadap luaran pada pasien anak penderita pneumonia. JMPF 2014;4:264-70.

18. Faizin C, Kusumawati W, Habib I. Evaluation of antibiotics prescription in pediatric patient. JMMR 2019;8:32-9.

19. Cusini A, Rampini SK, Bansai V, Ledergerber B, Kuster SP, Ruef C, dkk. Different patterns of inappropriate antimicrobial use in surgical and medical units at tertiary care hospital in Switzerland: a prevalence survey. Diakses pada 2 Agustus 2020. Didapat dari: https://www.ncbi.nlm.nih.gov/pmclarticles/ PMC2982822/pdf/pone.0014011.pdf.

20. Aryani DE, Hasmono D, Zairina N, Setiawan L. Analysis of antibiotics use in pediatric pneumonia patients aged 3 months - 5 years. FMI 2016;52:108-15.

21. Mathur S, Fuchs A, Bielick J, Van den Anker JN, Sharland M. antibiotics use for community aquired pneumonia in neonates and children: 2016 evidence update. Diakses pada 24 Juli 2020. Didapat dari: https://www.who. int/selectionmedicines/committees/expert/21/applications/ s6paedantibioticsappendix3cap.pdf.

22. Putra IW, Setyaningtyas A, Puspitasari D, Irwanto, Wahyu AD, Dharmawati I, dkk. Microbial pattern and antibiotic susceptibility in pediatric intensive care unit $\mathrm{dr}$ soetomo hospital Surabaya. Indonesian J Trop Infect Dis 2019;7:122-30. 